\section{С.В. Филатова*}

«Всем руководила его жена, а он все время проводил в своем кабинете... и писал стихи»: иерархия ролей в провинциальных дворянских и купеческих семьях второй половины XVIII - начала XX в.

DOI: $10.31518 / 2618-9100-2019-3-12$

УДК 323.328:392.3“17/19”+323.311:392.3“17/19”

Выходные данные для цитирования:

Филатова C.B. «Всем руководила его жена, а он все время проводил в своем кабинете... и писал стихи»: иерархия ролей в провинциальных дворянских и купеческих семьях второй половины XVIII - начала XX в. // Исторический курьер. 2019. № 3 (5). Статья 12. URL: http:// istkurier.ru/data/2019/ISTKURIER-2019-3-12.pdf

\section{S.V. Filatova*}

"Everything was led by his wife, while he spent all the time in his office... and wrote poems": hierarchy of roles in provincial noble and merchant families of the second half of $18^{\text {th }}-$ early $20^{\text {th }}$ centuries

\section{DOI: $10.31518 / 2618-9100-2019-3-12$}

How to cite:

Filatova S.V. "Everything was led by his wife, while he spent all the time in his office... and wrote poems": hierarchy of roles in provincial noble and merchant families of the second half of $18^{\text {th }}-$ early $20^{\text {th }}$ centuries // Historical Courier, 2019, \# 3 (5). Article 12. [Available online:] http://istkurier.ru/data/ 2019/ISTKURIER-2019-3-12.pdf

Abstract. The article is devoted to the problem of family relations in the nobility and merchant milieu in the late $18^{\text {th }}$ - early $20^{\text {th }}$ centuries. The Hierarchy of roles in families is examined in the context of revitalization of traditional values caused by socio-economic modernization in this period. The author comes to conclusion that at this time the development of the institution of the Russian family was determined by a combination of patriarchal, conservative and partnership, liberal trends. Society was critical of the extreme forms of manifestation of any of these options, regulating parity through legislation, the activities of public organizations and the system of public evaluation of approval or censure. Also, the role and influence of each spouse directly depended on such a factor as his or her contribution to the economic well-being of the family. Possession of property, first of all, real estate, and entrepreneural capacities provided a woman with the power in a family, allowed to make decisions and to decide the fates of family members, including her husband. In some cases, it could be a forced situation where a woman who does not have the support of a man, took responsibility for the financial security of the family. Of course, the characters of the spouses - will, energy, ambition - had a significant impact on the hierarchy of family roles. As a rule, commercial talents were combined with them, thus strengthening each other. The support of senior family members, influential friends, social activities also contributed to the strengthening of the status of women within the family. The sources of personal origin underlying this study provide concrete examples of the problem.

Keywords: hierarchy of roles; provincial family; nobility; merchant class; gender.

The article has been received by the editor on 07.02.2019.

Full text of the article in Russian and references in English are available below.

Аннотация. Статья посвящена проблеме внутрисемейных отношений в дворянской и купеческой среде России в конце XVIII - начале XX в. Иерархия ролей в семьях рассматривается в контексте обновления традиционных ценностей, вызванных социальноэкономической модернизацией в указанный период. Автор приходит к выводу, что в это время развитие института российской семьи определялось сочетанием патриархальных, консервативных и партнерских, либеральных тенденций. Общество критически относилось к

\footnotetext{
* Филатова Светлана Владимировна, кандидат исторических наук, преподаватель, Пензенский социальнопедагогический колледж (Пенза, Россия), e-mail: col4uginasvetlana@yandex.ru

Filatova Svetlana Vladimirovna, Candidate of Historical Sciences, lecturer, Penza Socio-pedagogical College (Penza, Russia), e-mail: col4uginasvetlana@yandex.ru
} 
крайним формам проявления какого-либо из указанных вариантов, регулируя паритет через законодательство, деятельность общественных организаций и систему общественных оценок одобрения или порицания. Роль и влияние каждого из супругов также напрямую зависели от такого фактора, как вклад в экономические благосостояние семьи. Владение собственностью, прежде всего недвижимой, и предпринимательские способности обеспечивали женщине власть в семье, позволяли принимать решения и распоряжаться судьбами своих домочадцев, в том числе мужа. В ряде случаев это могла быть вынужденная ситуация, когда женщина, не имеющая поддержки со стороны мужчины, брала на себя ответственность за материальную безопасность семьи. Разумеется, и особенности характеров супругов - воля, энергия, амбициозность оказывали значительное влияние на иерархию внутрисемейных ролей. Как правило, с ними сочетались и коммерческие таланты, усиливая таким образом друг друга. Поддержка старших членов семьи, влиятельных друзей, общественная деятельность также способствовали упрочнению внутрисемейного статуса женщины. Источники личного происхождения, лежащие в основе данного исследования, позволяют на конкретных примерах рассмотреть заявленную проблему.

Ключевые слова: провинциальная семья; дворянство; купечество; гендер; иерархия ролей.

$$
* * *
$$

Семейные отношения, распределение ролей, домашний уклад оказывают значительное влияние как на формирование отдельной личности, так и на социум в целом, определяют множество социальных процессов и явлений. Заявленная тема актуальна по целому ряду причин. Кризис современной российской семьи обусловливает интерес к семье конца XVIII начала XX в., поскольку в указанный период сохранение патриархальных, консервативных семейных традиций сопровождалось обновлением данного социального института. Ценности, идеалы, модели поведения, привитые и принятые в этих семьях, позднее распространялись на собственную семью, профессиональную деятельность, другие социальные практики.

Мы сочли возможным в настоящей работе объединить дворянские и купеческие семьи в одну группу, хотя по некоторым параметрам они существенно отличались. Женщина из дворянской среды, особенно в начале исследуемого периода, была более образованна, в большей степени вовлечена в общественную жизнь, что обеспечивало ей дополнительные рычаги влияния на других членов семьи. Купеческая жена, дочь или сестра таких преимуществ не имела. Однако она (речь здесь идет особенно о первом поколении купцов, происхождением связанном с крестьянской или мещанской средой) была менее связана «правилами приличия», стереотипами, условностями. В данном случае отсутствие такого аскриптивного статуса, как принадлежность к купеческому сословию, давало ей определенную свободу. Логично также предположить, что на внутрисемейные взаимоотношения непосредственное влияние оказывала профессиональная деятельность мужчин. Так, у купца, владеющего торговым предприятием, развивались такие качества, как толерантность, вежливость, умение идти на компромиссы, слышать собеседника и договариваться. Вряд ли такие черты были присущи дворянину-крепостнику.

В то же время семейный уклад и в дворянской среде, и в купеческой определялся схожими факторами. Это - наличие собственности, отсутствие или малое значение тяжелого физического труда в процессе сохранения и приумножения семейного благосостояния, высокий (относительно представителей многих других страт общества) образовательный уровень, время для досуга.

Кроме того, выбор данных категорий был обусловлен спецификой источниковой базы. Существует проблема, связанная, с одной стороны, с огромным массивом источников по обозначенной проблеме, а с другой - со сложностью их обработки. Посемейных списков, позволяющих судить о структуре семьи, взаимоотношениях ее членов, недостаточно, часто такие списки неполные. Для решения этой проблемы существуют различные методики. 
Так, коллективом исследователей из Тамбова для изучения городских семей были созданы базы данных на основе массовых персоницифированных источников: выборки данных ревизий, «Списков обывателей» Тамбова, метрических книг, окладных книг на недвижимое имущество горожан, адрес-календарей, списков избирателей в Учредительное собрание. Данная программа позволяет выявить главу семьи, статус различных ее членов, провести моделирование семейных связей, изучить экономические характеристики ${ }^{1}$. Однако этот алгоритм не в состоянии учесть все возможные варианты разветвления семей, распределения внутрисемейных ролей. В отношении дворянских семей также существуют свои проблемы ревизский учет в отношении них не велся, а посемейные списки составлялись редко. Источниками, содержащими наибольший массив информации, можно считать дела о дворянских родах с генеалогическими сведениями, но и их недостаточно ${ }^{2}$. Вот почему необходимо привлечение источников другого рода, например, личного происхождения.

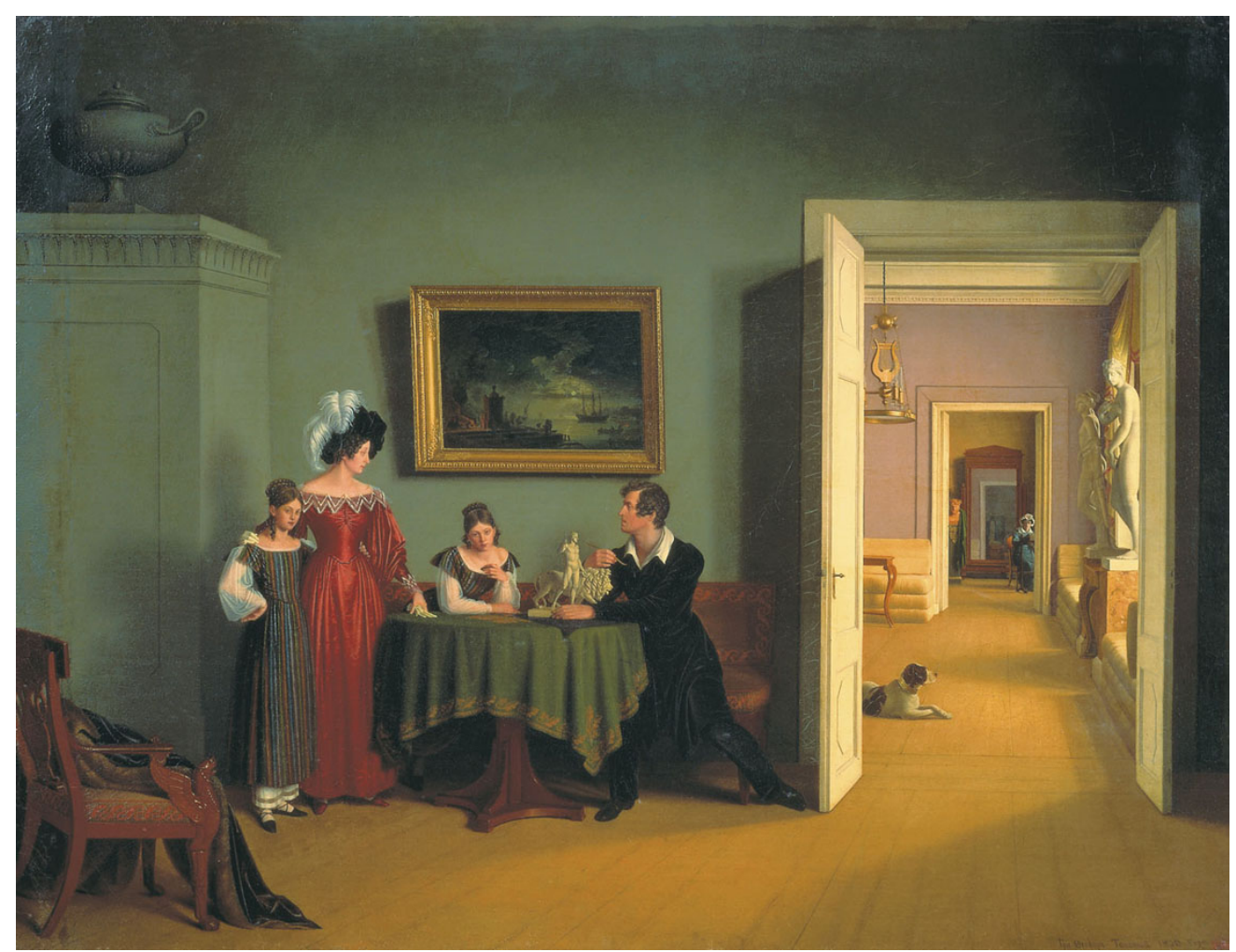

Ф.П. Толстой. Семейный портрет (1830)

Мемуары, дневники, эпистолярное наследие достаточно содержательны с точки зрения выяснения отношений в семье и семейной иерархии. В основном они не противоречат идее об андроцентричной модели российской семьи, распространенной в научной литературе. То обстоятельство, что среди семей дворянства и городских жителей вплоть до середины XIX в. преобладали модели, основанные на патриархально-авторитарных отношениях, имело объективные основания. Е.В. Банникова, ссылаясь на П. Берлина, в качестве причины, способствующей такому порядку в семье, называет особенности первоначального накопления капитала, формирующие у участников данного процесса такие качества, как безжалостность, беспринципность, грубость. Эта модель поведения переносилась и на внутрисемейные отношения ${ }^{3}$. Кроме того, мужья были довольно часто намного старше своих жен, женщины были заняты рождением детей, уходом за ними и их воспитанием.

\footnotetext{
${ }^{1}$ Канищев В.В., Кончаков Р.Б., Стрекалова Н.В. Технология восстановления структуры городской семьи 1917 г. // Информационный бюллетень ассоциации «История и компьютер». 2006. № 34. С. 115.

${ }^{2}$ Канищев B.B., Шуваев Д.А. База данных «Дворянская семья»: проблемы создания и интерпретации // Информационный бюллетень ассоциации «История и компьютер». 2010. № 36. С. 69.

${ }^{3}$ Банникова E.B. «Не печалься, моя Душечка...». Супружеские отношения в провинциальной купеческой семье // Пол. Политика. Поликультурность. Гендерные отношения и гендерные системы в прошлом и настоящем: Материалы VII Междунар. науч. конф. РАИЖИ и ИЭ РАН. М., 2014. Т. 1. С. 152-153.
} 
Деторождение нередко подрывало женское здоровье, и в таких условиях роль мужчины в доме была доминирующей ${ }^{4}$. Глава династии управлял распоряжался судьбами всех членов семьи. Его приказания должны были выполняться беспрекословно, ослушавшихся подвергали наказанию, в том числе физическому. Такой «патриарх» единолично решал все значимые вопросы, распоряжался имуществом семьи, женил детей по своему разумению, мог отдавать их в работы против воли или определять на службу (отличие главы семьи в дворянской среде заключалось лишь в том, что его господство носило утонченный, просвещенный характер). В то же время нельзя говорить о какой-то невероятной тирании. Поскольку внутрисемейные отношения имели в той или иной степени публичный характер (каждая семья находилась в контакте, с одной стороны, с родственниками, а с другой - с соответствующими корпорациями), деспотизм и семейный произвол сдерживался такими механизмами, как общественные оценки одобрения или порицания5.

Во второй половине XIX - начале XX в. сохранялись многие патриархальные черты и, в то же время, усиливалась гуманизация внутрисемейных отношений (в первую очередь это коснулось горожан). Данный процесс был связан с общей либерализацией социума, ростом образованности населения, а также с постоянно увеличивающейся долей женского труда в экономике страны (буржуазная модернизация значительно расширила спектр возможностей для дамы быть полезной в экономической деятельности). Для женщины «нового типа» стала характерной эгоцентрическая модель поведения и самоощущения: она готова к творческой самореализации, самостоятельности в действиях, стремлению тратить время на себя, самостоятельному выбору времяпрепровождения. Эти качества ранее были прерогативой в основном «мужского мира». В результате в семейной жизни такая женщина стала менее склонна к следованию патриархальной традиции (нередко испытывая при этом ролевой конфликт) ${ }^{6}$.

Однако и в дореформенную эпоху, и в период буржуазной модернизации на страницах мемуарной литературы нередко оживают образы сильных, властных, амбициозных женщин, знающих, чего они хотят от жизни, способных постоять за себя и за тех, кто им дорог.

На наш взгляд, ответ на вопрос «Кто в доме хозяин?» был связан с целым рядом факторов, главнейший из которых - вклад в семейное благосостояние. Нами подробно рассмотрен вопрос о возможностях для женщин заниматься предпринимательской деятельностью, предоставляемых российским законодательством ${ }^{7}$. Женщины, принадлежавшие к дворянскому или купеческому сословию, нередко единолично владели имуществом, сопоставимым или даже превосходившим размеры имущества мужа. Кроме того, мужья нередко подолгу отсутствовали, будучи заняты на государственной и военной службе, обременены какими-либо общественными обязанностями. Проблему представлял и разгульный образ жизни сильного пола: пьянство, мотовство, увлечение карточными играми. Кто-то просто не желал утруждать себя хозяйственными делами. В данных условиях бремя заботы о хлебе насущном ложилось на жену, которая, ввиду ответственности за выживание и благополучие детей, проявляла недюжинную деловую хватку ${ }^{8}$ Поскольку в России уже в середине XVIII в. представительницы дворянского сословия получили право владеть и распоряжаться собственностью, они, по мнению М.Л. Маррезе, нередко управляли семейным

\footnotetext{
${ }^{4}$ Банникова E.B. Повседневная жизнь провинциального купечества (на материалах губерний Урала дореформенного периода СПб., 2014. С. 279.

${ }^{5}$ Миронов Б.Н. Социальная история России периода империи (XVIII - начало XX в.): генезис личности, демократической семьи, гражданского общества и правового государства: в 2-х томах. СПб., 2000. Т. 1. С. 255$257,260$.

${ }^{6}$ Меньшикова Е.Н., Семенов М.Ю. Конструирование репрезентативного образа женщины «нового типа» конца XIX-начала XX века // Историческая психология и социология истории. 2014. Т. 7. № 2. С. 128.

${ }^{7}$ Филатова С.В. Эволюция предпринимательской правоспособности русской женщины с древности до начала XX века // XXI век: итоги прошлого и проблемы настоящего плюс. 2011. № 2 (02). С. 155-161.

${ }^{8}$ Белова A.B. Экономическая активность провинциальной дворянки П.И. Манзей // Материальный фактор и предпринимательство в повседневной жизни населения России: история и современность: Материалы Междунар. науч. конф. СПб, 2016. С. 295-300.
} 
имуществом в целом. В мемуарной литературе XVIII-XIX вв. «и мысли нет о том, что дворянки, которые хозяйничают в имениях и заботятся о своих финансовых интересах, нарушают нормы женского поведения, как и о том, что мужчин в их семьях унижает открытое проявление женских деловых качеств» ${ }^{9}$.

Так, Н.Е. Струйский, один из богатейших людей Поволжья, поселившись в своем наследственном имении с. Рузаевке, «предался поэзии, писал много стихов, у него была своя типография, переплетал свои книги в глазет, сафьян и пергамент; он имел большую библиотеку русских и французских книг. Имея громадные средства, он жил по-царски, женился на 13-летней (информация по этому поводу противоречива, возможно, Александре Петровне Озеровой на момент заключения брака было не менее 17-ти лет. - С.Ф.) красавице из хорошей семьи [...]. Всем руководила его жена, а он все время проводил в своем кабинете, который называл Парнасом, и писал стихи» ${ }^{10}$. Вот еще несколько штрихов к портрету одной из красивейших женщин своего времени (и матери восемнадцати детей): «Госпожа Струйская проникла во все таинства благоразумного хозяйства. Земледелие ей так знакомо, как другим сестрам ее выкройка модного платья; она пользуется нарочитым доходом» ${ }^{11}$. Видимо, эта ситуация была типичной для того времени. Образ матери

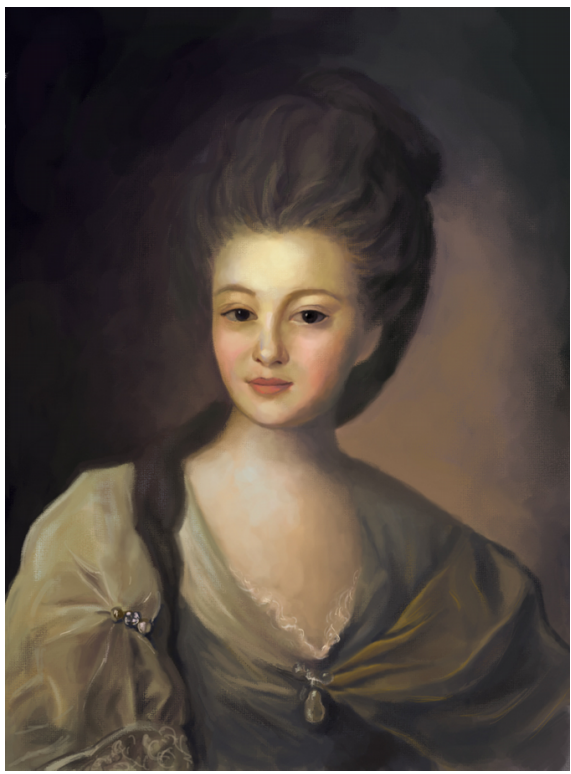

Ф.С. Рокотов. Портрет Александры Петровны Струйской (1772) семейства Лариных, созданный А.С. Пушкиным в романе «Евгений Онегин», производит впечатление деятельной, энергичной хозяйки: «Она езжала по работам, // Солила на зиму грибы, // Вела хозяйство, брила лбы, // Ходила в баню по субботам, // Служанок била, осердясь - // Все это мужа не спросясь...» Именно заботы по хозяйству примирили Рachette c браком, заключенным вопреки ее воле: «Она меж делом и досугом // Открыла тайну, как супругом // Самодержавно управлять, // И все тогда пошло на стать». Результат - вполне гармоничная семейная жизнь, поскольку «...муж любил ее сердечно, // В ее затеи не входил, // Во всем ей веровал беспечно, // А сам в халате ел и пил...» ${ }^{12}$.

После отмены крепостного права экономическая роль женщины-дворянки в семье еще более возросла. Если в дореформенный период идеал хорошей хозяйки сводился в основном к контролю за деятельностью многочисленного персонала - будь то дворня или управляющий имением (заводом, фабрикой), то с 1860-х гг. многие дворянки стали вынуждены экономить на прислуге. Как отмечает В.А. Веременко, «по мере того, как экономические изменения приобретали кардинальный характер и значительно ухудшалось положение первенствующего сословия, все меньше дворян могли позволить себе даже то количество прислуги, которое рассматривалось как минимальное». В результате хозяйка, особенно городская, была вынуждена брать на себя реальное выполнение домашних обязанностей, сохраняя тем самым энную сумму в бюджете семьи ${ }^{13}$.

Такой тип семьи В.А. Веременко условно называет «новая практическая дворянская семья». Ставший достаточно заметным явлением в 1860-е гг., к началу XX в. он превратился в доминирующий. Внутрисемейное распределение труда в этом случае предполагало

\footnotetext{
${ }_{9}^{9}$ Маррезе М.Л. Бабье царство: Дворянки и владение имуществом в России (1700-1861). М.: Новое литературное обозрение, 2009. С. 259.

${ }^{10}$ [Струйская] E.C. Усадьба Струйских «Рузаевка» // Столица и усадьба. 1915. № 38-39 (1 авг.). С. 4.

${ }_{11}$ Долгоруков И.М. Журнал путешествия из Москвы в Нижний 1813 года. М., 1870. С. 78.

${ }^{12}$ Пушкин А.С. Евгений Онегин // Собрание сочинений: в 10 т. М., 1960. Т. 4. С. 49-50.

${ }^{13}$ Веременко B.A. Хозяйка на кухне: адаптационные практики в жизни российской дворянской семьи во второй половине XIX - начале XX в. // Экстремальное в повседневной жизни населения России: история и современность (к 100-летию русской революции 1917 г.): Материалы Междунар. науч. конф. СПб., 2017. C. $316-318$.
} 
активный «трудовой вклад» жены в семейный бюджет. Этот процесс мог осуществляться тремя способами: работа вне дома (акушеркой, журналисткой, учительницей), в доме и на дому. Речь идет об уже упоминавшейся экономии на прислуге, а также о труде ручном (шитье, вышивание, расписывание посуды) и интеллектуальном (переписывание разного рода материалов, помощь в составлении документов, переводы). Промежуточное положение между работой в доме и на дому занимал труд квартирной хозяйки ${ }^{14}$.

Вот история из жизни такой семьи. В.С. Семибратов, пензенский инспектор народных училищ, чиновник «с положением», владелец собственного двухэтажного дома в губернском центре, «в 45 лет, уйдя со службы на крохотную [...] пенсию, совсем опустился. Никакого участия в семейных делах не принимал, сидел в кресле у окошка, грыз семечки или, еще лучше: ставил на подоконник блюдце с касторкой, макал в нее кусочки черного хлеба и с удовольствием ел». Все тяготы жизни обрушились на его супругу. Чтобы прокормить большую семью (у Семибратовых было шестеро детей), Серафима Николаевна стала брать «нахлебников» - детей из деревень, сел, уездных городов, обучающихся в Пензе. Они «становились» на частных квартирах с питанием - «на хлеба». Неудивительно, что родные дети Серафимы Николаевны чрезвычайно ее любили. По прошествии лет ее внучка Татьяна писала: «Все мои дяди и тетки [...] относились к ней с большим вниманием и уважением [...], постоянно ее вспоминали, заботились о ней, а об отце [...] никогда не упоминали: видно, хорошего вспоминать было мало чего...» ${ }^{15}$.

Сходные процессы наблюдались и в купеческой семье. Выполнение определенных домашних работ в купеческой среде традиционно считалось обязанностью женщины; тем не менее, многие дамы вполне успешно занимались и коммерческой деятельностью, право на ведение которой за ними было законодательно закреплено: лица женского пола причислялись к купеческому сословию наравне с мужчинами. Жена могла вести торговлю даже вопреки воле мужа. Многие женщины, даже не будучи самостоятельными хозяйками дела, принимали активное участие в бизнесе супруга, особенно во время его отсутствия. Мужья вполне полагались на жен, которые во время их отлучек выступали в качестве своего рода посредников и контролеров между мужем-хозяином и работавшими на него приказчиками ${ }^{16}$. Кто-то из женщин в письмах мужьям сообщал все подробности о коммерческих делах и просил совета ${ }^{17}$, а кто-то принимал решения самостоятельно. Так, Е.Н. Меньшикова на примере купеческого семейства Гладковых из Курской губернии убедительно демонстрирует весьма значительную роль некоторых женщин-купчих в семейной экономике. В частности, в одном из писем к родителям М.И. Слатина (в девичестве Гладкова) просит отца защитить интересы ее мужа. Василий, брат Марии, взял в долг у ее супруга И.И. Слатина, по-видимому, крупную сумму денег и не смог вовремя вернуть. Мария неоднократно обращалась к отцу, ссылаясь на его авторитет, с просьбой убедить брата вернуть долг ${ }^{18}$. Неудивительно, что при таком положении вещей между супругами складывались уважительные, равные, партнерские отношения.

Факт признания мужьями предпринимательских способностей жен нашел отражение и в институте наследования купеческого дела. Даже при наличии взрослых дееспособных

\footnotetext{
${ }^{14}$ Веременко В.А. Дворянская семья и государственная политика России (вторая половина ХІХ - начало ХX в.). СПб., 2009. С. 413-416.

${ }^{15}$ Семибратова T.B. Записки о пензенской родне // Земство: Архив провинциальной истории России. Пенза, 1995. № 1. C.71-72, 75 .

${ }^{16}$ Комлева Е.В. Из наследия красноярских купцов Ларионовых. Новосибирск, 2016. Вып. 1. Письма конца XVIII - первой трети XIX в. С. 77-78.

${ }^{17}$ Маслова И.В. Структура родственных связей и традиции семейного быта уездного купечества в Вятской губернии в XIX - начале XX в. // Известия Волгоградского государственного педагогического университета. 2009. № 8 (42). C. 151.

${ }^{18}$ Меньшикова E.H. Анализ «выдающихся черт» исторического облика женщины-купчихи провинциальной России в 60-90-е гг. XIX в. (На примере купеческого семейства Гладковых из Курской губернии) // Женщина в российском обществе. 2012. № 2. С. 30 .
} 
сыновей нередко главами семей при жизни составлялись завещания, согласно которым имущество и руководство предприятием переходило в руки матерей семейства ${ }^{19}$.

Отметим также, что женщины, принадлежавшие к купеческому сословию, могли быть компетентны не только в торговых делах. Образ просвещенной, образованной купчихи с середины XIX в. уже не редкость на страницах мемуарной литературы. Как указывает И.В. Маслова, «многие купчихи были хорошо образованными женщинами, владели несколькими языками и придерживались прогрессивных для своего времени взглядов» ${ }^{20}$. Например, русский писатель, поэт И.Т. Калашников отмечал в своих записках обширные познания купеческой дочери Е.А. Полевой, которая «прекрасно говорила и вела политический разговор о тогдашнем положении Европы» ${ }^{21}$.

Немалое значение для семейных отношений имели личностные качества конкретного человека. В частности, волевые, властные женщины, безусловно, оказывали весомое влияние на жизнь своих домочадцев. Так, трагедия, произошедшая в 1754 г. в семье пензенского воеводы А.П. Жукова, была спровоцирована женщинами. Старший сын Жуковых, Алексей, «женился не спросясь, и еще более того [...] он получил за женой в приданое только три тысячи руб. вместо шести, как ему было обещано». Свекровь невестку свою «постоянно бранила и даже, при случае, бивала. Сын требовал от матери денег для уплаты долгов мать денег ему не давала и еще более сердилась». Деньги же молодоженам требовались «дозарезу» и они нашли выход - «покончить со старухой», ограбив ее. Это намерение поддержала Анастасия Полтева, теща Алексея. Исполнителями преступления стали крепостные, которым пообещали свободу и деньги. В результате погибла не только Агриппина Жукова, но и ее младшая дочь, делившая спальню с матерью ${ }^{22}$.

В автобиографическом рассказе «Последние

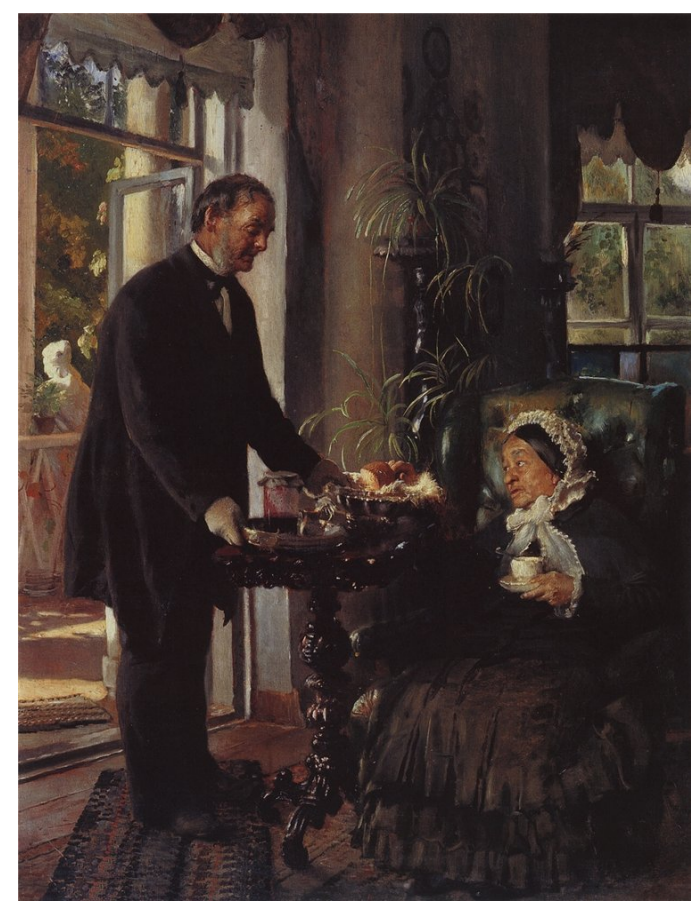

К.Е. Маковский. Помещчица (1886) дни Помпеи» русско-польский писатель И.Н. Неверли (Абрамов) рисует весьма колоритный портрет матери своего отчима. Эта дама, Анастасия Поликарповна, «чертовка византийская», «властвовала у себя дома, изводя мужа и двух сыновей». Когда старший сын влюбился в модистку, она не согласилась на этот брак - «пусть, мол, выкинет из головы эту дурацкую, неподобающую любовь». «Сын воспринял ее слова как приказ и пустил себе пулю в лоб» ${ }^{23}$. Е.А. Золотарева, пензенская помещица, также открыто руководила действиями мужа «твердость воли у нее была мужская», «безошибочно можно было ее назвать женатою» ${ }^{24}$.

\footnotetext{
19 Зайцева О.М., Стрекалова Н.В. Женщина купеческого сословия г. Тамбова в конце XIX - начале XX века: штрихи к социальному портрету // Вестник Тамбовского университета. Серия Гуманитарные науки. Тамбов, 2018. Т. 23. № 1 (171). С. 150.

${ }^{20}$ Маслова И.В. Культура семейных традиций уездного купечества Вятской губернии в XIX - начале XX века // Вестник Воронежского государственного университета. Серия: История. Политология. Социология. 2011 . № 1. C. 122 .

${ }^{21}$ Цит. по: Комлева Е.В. «Господствующий класс»: сибирские купцы в эго-текстах чиновников (конец XVIII XIX в.) // Личность, общество и власть в истории России: Сб. науч. статей, посв. 70-летию д-ра истор. наук, проф. В.И. Шишкина. Новосибирск, 2018. С. 59.

${ }^{22}$ Корольков М.Я. Матереубийцы. (Процесс Жуковых. Эпизод из судебной хроники XVIII столетия) // Русская старина. 1908. Т. СХ ХХІІІ. Вып. 1-3. С. 227.

${ }^{23}$ Неверли (Абрамов) И.Н. Последние дни Помпеи // Пензенский край в мемуарах, художественной литературе и исследованиях: Антология. М., 2014. Т. 1. С. 246-247.

${ }^{24}$ Вигель Ф.Ф. Записки: в 2-х кн. М., 2003. Кн. 2. С. 701.
} 
Особенно деспотично женщины вели себя по отношению к членам своей семьи в пожилом возрасте. Получив, иногда только в конце жизни, свободу принятия решений при объективном возрастании с годами социальных потенций и амбиций, и в то же время, будучи уже ограниченной в возможностях физических (вследствие болезни) и социальных (отсутствие мобильности), мать семейства нередко по-настоящему третировала еще более старого мужа и взрослых детей. При этом, как отмечает А.В. Белова, молодые домочадцы практически не сопротивлялись эмоциональному диктату пожилых матерей «ввиду интериоризованных стереотипов подчинения и необходимости признания авторитета родительницы» ${ }^{25}$.

Подобные модели поведения существовали и в купеческой среде. Н.В. Обнорская повествует о печальной семейной жизни состоятельных ярославских купцов Огняновых. Постоянная ругань, попреки и рукоприкладство - вот как можно охарактеризовать порядки, заведенные в доме матерью семейства. Супруга Д.М. Огнянова, Серафима Георгиевна, «мужа со временем довела до такого состояния, что он потерял дар нормальной речи, хотя при этом все прекрасно понимал. Его бессвязные слова мог понимать и «переводить» только один преданный слуга. Причем Серафима Георгиевна не стеснялась при людях называть мужа «дураком» ${ }^{26}$.

В подтверждение данного тезиса уместно привести в пример историю семейной драмы

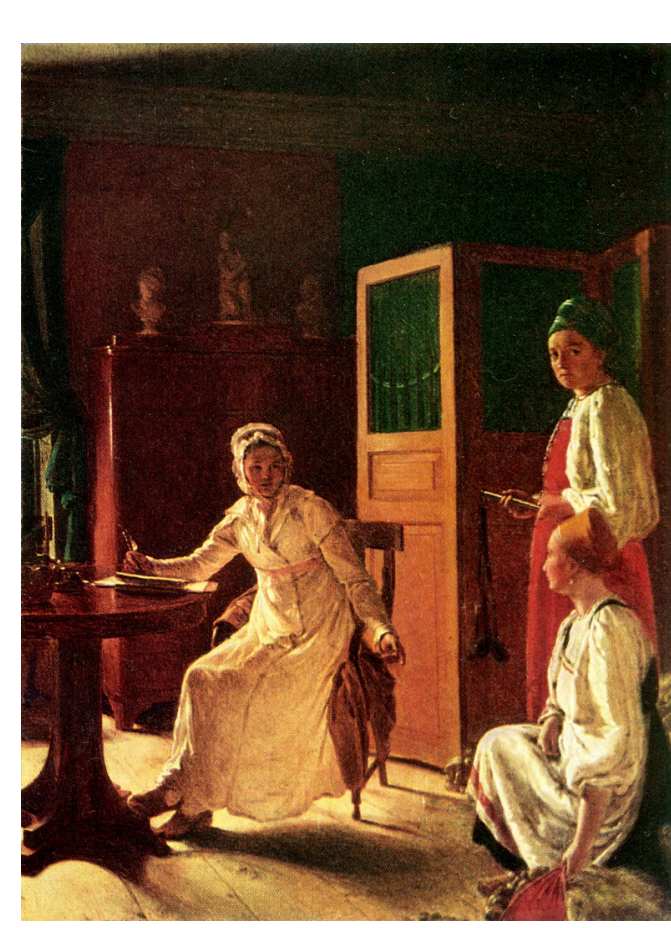
родителей М.Ю. Лермонтова. Брак Марии Михайловны Арсеньевой и Юрия Петровича Лермонтова, заключенный, видимо, по большой сердечной склонности, не вызвал одобрения матери новобрачной, Елизаветы Алексеевны. Причиной такого отношения тещи к зятю исследователь П.А. Фролов называет чувство ревности. Рано овдовев, Е.А. Арсеньева стала «носительницей губительной ревнивой любви к дочке», единственному ребенку. Позднее то же чувство овладело ею по отношению к внуку. Е.А. Верещагина, родственница Арсеньевой, сообщала в одном из своих писем о беспокойстве Елизаветы Алексеевны, которая «все думает, что Мишу женют, все ловют». Ревнивая бабушка слышать не желала, «чтоб Миша при ней женился, любить будет жену, говорит, и [...] это ее измучит, и не хочу, [говорит], чтоб он при жизни моей женился».

В качестве рычага воздействия на младших членов своей семьи Е.А. Арсеньева использовала финансы. Традиционно создание новой семьи в дворянской среде строилось на следующих принципах: муж А.Г. Венецианов. Утро помещициы (1823)

обеспечивает жилище, жена - приданое. Помещики-родители, выделявшие в приданое своим дочерям землю и крестьян, оглашали это заблаговременно. Делалось это открыто, объявленное состояние девушки на выданье вызывало дополнительный интерес со стороны будущих женихов, и семья невесты могла выбирать из большего числа претендентов. Елизавета Алексеевна также заранее могла подготовить приданое дочери, но она этого не сделала. Более того, Е.А. Арсеньева всячески препятствовала тому, чтобы в собственности дорогих ей людей находились ресурсы, позволившие им освободиться от ее власти. Так,

\footnotetext{
${ }^{25}$ Белова А.В. «Четыре возраста женщины»: Повседневная жизнь русской провинциальной дворянки XVIII середины ХІХ в. СПб., 2010. С. 440.

${ }^{26}$ Обнорская H.B. «Все счастливые семьи похожи друг на друга, каждая несчастливая семья несчастлива посвоему»: семейные драмы в повседневной жизни купечества Ярославской губернии второй половины XIX начала XX века // Семейная жизнь. Счастливые и драматические истории на фоне городской повседневности: Материалы науч. семинара, посв. исследованиям проблем истории повседневности. Оренбург, 2018. С. 92-93.
} 
после смерти отца, М.В. Арсеньева, Марии Михайловне досталось небольшое имение. В 1811 г. за ней числились наделенные землей крестьяне: 16 душ мужского пола. Также наследство получила и Елизавета Алексеевна, которая могла бы отказаться от своей доли в пользу дочери (в ее личном владении было около 500 крепостных). Однако она не только не сделала этого, но при разделе округлила имущество покойного супруга в свою пользу. Вместо 20 крестьян мужского пола дочь получила только 16 (семьи нельзя было дробить).

Также Мария Михайловна в результате раздела имения её бабушки и дедушки Арсеньевых имела в собственности не менее 25 тыс. руб. Эта сумма вполне могла компенсировать отсутствие у нее приданого, но Елизавета Алексеевна не спешила передавать ее молодой семье. Существует документ, относящийся к 1819 г. (брак же Лермонтовых был заключен не позднее 1814 г.), который может быть расценен как подтверждение факта передачи. Но это - запись канцеляриста; подписи Юрия Петровича нет.

Далее - небольшая крепостная собственность матери должна была перейти к ее сыну-наследнику после смерти последней в 1817 г. Но М.Ю. Лермонтов не стал ее владельцем. С помощью подлога его бабушка подменила бывших дочерних крестьян с землей на своих безземельных дворовых. С подменой собственности статус дворянина Михаила Лермонтова существенно понизился. В том же 1817 г. Елизаветой Алексеевной было составлено завещание, в котором она единственным своим наследником объявляет

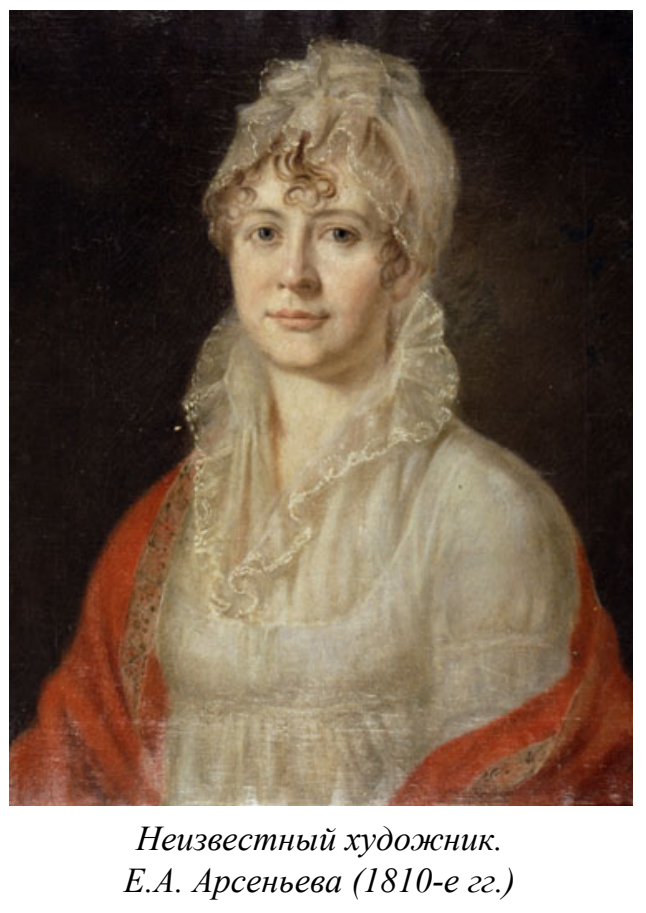
внука. Но этот документ содержит ряд условий, а именно: «внук мой будет по жизнь мою находиться при мне на моем воспитании и попечении без всякого на то препядствия (так в документе. - Авт.) отца его» ${ }^{27}$.

Подводя итог вышесказанному, можно отметить, что патриархальный уклад, определявший основные векторы развития общества в конце XVIII - начале XIX в., не был единственным механизмом, регулировавшим внутрисемейные отношения. Среди факторов, определявших иерархию ролей в семье, важное (а нередко и определяющее) значение имели экономические (владение имуществом, коммерческая инициатива) и личностные (ум, образованность, воля, амбиции). Приведенные примеры показывают, что общее преобладание патриархального семейного уклада в дворянско-купеческой среде в течение рассматриваемого периода не мешало отдельным представительницам прекрасного пола занимать доминирующее положение во внутрисемейных отношениях.

\section{Лumepamypa}

Банникова E.B. «Не печалься, моя Душечка...». Супружеские отношения в провинциальной купеческой семье // Пол. Политика. Поликультурность. Гендерные отношения и гендерные системы в прошлом и настоящем: Материалы VII Междунар. науч. конф. РАИЖИ и ИЭ РАН. М., 2014. Т. 1. С. 152-156.

Банникова E.B. Повседневная жизнь провинциального купечества (на материалах губерний Урала дореформенного периода). СПб.: Полторак, 2014. 440 с.

Белова А.В. Экономическая активность провинциальной дворянки П.И. Манзей // Материальный фактор и предпринимательство в повседневной жизни населения России: история и современность: Материалы Междунар. науч. конф. СПб., 2016. С. 295-300.

\footnotetext{
27 Фролов П.А. Создание и крушение семьи Лермонтовых // Сура: Журнал современной литературы, культуры и общественной мысли. Пенза, 2010. № 3. С. 151, 167-169, 173-175; № 4. С. 138, 152-154.
} 
Белова А.В. «Четыре возраста женщины»: Повседневная жизнь русской провинциальной дворянки XVIII - середины XIX в. СПб.: Алетейя, 2010. 480 с.

Веременко B.A. Дворянская семья и государственная политика России (вторая половина XIX-начало XX в.). СПб.: Европейский Дом, 2009. 684 с.

Веременко B.A. Хозяйка на кухне: адаптационные практики в жизни российской дворянской семьи во второй половине XIX - начале XX в. // Экстремальное в повседневной жизни населения России: история и современность (к 100-летию русской революции 1917 г.): Материалы Междунар. науч. конф. СПб., 2017. С. 315-323.

Вигель Ф.Ф. Записки: в 2-х кн. М.: Захаров, 2003. Кн. 2.752 с.

Долгоруков И.М. Журнал путешествия из Москвы в Нижний 1813 года. М.: Общество истории и древностей российских при Московском Университете, 1870. 122 с.

Зайцева O.M., Стрекалова Н.В. Женщина купеческого сословия г. Тамбова в конце XIX начале XX века: штрихи к социальному портрету // Вестник Тамбовского университета. Серия Гуманитарные науки. Тамбов, 2018. Т. 23. № 1 (171). С. 145-155.

Канищев В.В., Кончаков Р.Б., Стрекалова Н.В. Технология восстановления структуры городской семьи 1917 г. // Информационный бюллетень ассоциации «История и компьютер». 2006. № 34. C. 120-122.

Канищев В.В., Шуваев Д.А. База данных «Дворянская семья»: проблемы создания и интерпретации // Информационный бюллетень ассоциации «История и компьютер». 2010. № 36. С. 69-70.

Кольчугина C.В. Эволюция предпринимательской правоспособности русской женщины с древности до начала XX века // XXI век: итоги прошлого и проблемы настоящего плюс. 2011. № 2 (02). С. 155-161.

Комлева E.B. «Господствующий класс»: сибирские купцы в эго-текстах чиновников (конец XVIII-XIX в.) // Личность, общество и власть в истории России: Сб. науч. статей, посв. 70-летию д-ра истор. наук, проф. В.И. Шишкина. Новосибирск, 2018. С. 53-73.

Комлева Е.В. Из наследия красноярских купцов Ларионовых. Новосибирск: Академиздат, 2016. Вып. 1: Письма конца XVIII - первой трети XIX в. 324 с.

Корольков М.Я. Матереубийцы. (Процесс Жуковых. Эпизод из судебной хроники XVIII столетия) // Русская старина. 1908. Т. СХ ХХІІІ. Вып. 1-3. С. 225-231.

Маррезе М.Л. Бабье царство: Дворянки и владение имуществом в России (1700-1861). М.: Новое литературное обозрение, 2009. 368 с.

Маслова И.В. Культура семейных традиций уездного купечества Вятской губернии в XIX - начале XX века // Вестник Воронежского государственного университета. Серия: История. Политология. Социология. 2011. № 1. С. 121-126.

Маслова И.В. Структура родственных связей и традиции семейного быта уездного купечества в Вятской губернии в XIX - начале XX в. // Известия Волгоградского государственного педагогического университета. 2009. № 8 (42). С. 148-151.

Меньшикова E.H. Анализ «выдающихся черт» исторического облика женщины-купчихи провинциальной России в 60-90-е гг. XIX в. (На примере купеческого семейства Гладковых из Курской губернии) // Женщина в российском обществе. 2012. № 2. С. 24-33.

Меньшикова Е.Н., Семенов М.Ю. Конструирование репрезентативного образа женщины «нового типа» конца XIX-начала XX века // Историческая психология и социология истории. 2014. T. 7. № 2. С. 117-131.

Миронов Б.Н. Социальная история России периода империи (XVIII - начало XX в.): генезис личности, демократической семьи, гражданского общества и правового государства: в 2-х томах. Т. 1. СПб.: Дмитрий Буланин, 2000. 548 с.

Неверли (Абрамов) И.Н. Последние дни Помпеи // Пензенский край в мемуарах, художественной литературе и исследованиях: Антология. М.: Новые решения, 2014. Т. 1. C. 243-256.

Обнорская Н.В. «Все счастливые семьи похожи друг на друга, каждая несчастливая семья несчастлива по-своему»: семейные драмы в повседневной жизни купечества Ярославской 
губернии второй половины XIX-начала XX века // Семейная жизнь. Счастливые и драматические истории на фоне городской повседневности: Материалы науч. семинара, посв. исследованиям проблем истории повседневности. Оренбург, 2018. С. 87-94.

Пушкин А.С. Евгений Онегин // Собрание сочинений: в 10 т. М.: Государственное издательство художественной литературы, 1960. Т. 4. С. 5-200.

Семибратова T.B. Записки о пензенской родне // Земство: Архив провинциальной истории России. Пенза, 1995. № 1. С. 67-99.

Стрекалова Н.В. К проблеме использования информационных методов и технологий в исследованиях провинциальной городской семьи конца XVIII - начала XX в. // Цифровая гуманитаристика: ресурсы, методы, исследования: Материалы Междунар. науч. конф. Пермь, 2017. Ч. 2. С. 114-117.

[Струйская] E.C. Усадьба Струйских «Рузаевка»// Столица и усадьба. 1915. № 38-39 (1 авг.). С. 3-5.

Фролов П.А. Создание и крушение семьи Лермонтовых // Сура: Журнал современной литературы, культуры и общественной мысли. Пенза, 2010. № 3. С. 151-184; № 4. С. 124160.

\section{References}

[Struiskaya] E.S. (1915). Usad'ba Struyskih "Ruzaevka" [Struiskiye's Estate "Ruzaevka"]. In Stolica i usad'ba. No. 38-39 (1 August), pp. 3-5.

Bannikova, E.V. (2001). "Ne pechal'sya, moya Dushechka...". Supruzheskie otnosheniya v provintsial'noy kupecheskoy sem'e ["Don't be sad, my Dushechka...". Marital relations in a provincial merchant family]. In Pol. Politika. Polikul'turnost'. Gendernye otnosheniya i gendernye sistemy v proshlom i nastoyashhem: Materialy VII Mezhdunar. nauch. konf. RAIZHI $i$ IEH RAN. Moscow. Vol. 1, pp. 152-156.

Bannikova, E.V. (2014). Povsednevnaya zhizn' provintsial'nogo kupechestva (na materialakh guberniy Urala doreformennogo perioda) [The daily life of the provincial merchant class (on the materials of the pre-reform period, the provinces of the Urals)]. St. Petersburg, "Poltorak" Publ. $439 \mathrm{p}$.

Belova, A.V. (2010). “Chetyre vozrasta zhenshhiny”: Povsednevnaya zhizn' russkoy provintsial'noy dvoryanki XVIII - serediny XIX v. ["Four age women": the Daily life of the Russian provincial noblewoman $18^{\text {th }}-$ mid- $19^{\text {th }}$ century]. St. Petersburg, Aletheia. $480 \mathrm{p}$.

Belova, A.V. (2016). Ekonomicheskaya aktivnost' provintsial'noy dvoryanki P.I. Manzey [Economic activity provincial noblewoman P.I. Manzey]. In Material'niy faktor $i$ predprinimatel'stvo $v$ povsednevnoy zhizni naseleniya Rossii: istoriya i sovremennost': Materialy Mezhdunar. nauch. konf. St. Petersburg, pp. 295-300.

Dolgorukov, I.M. (1870). Zhurnal puteshestviya iz Moskvy v Nizhniy 1813 goda [Magazine travel from Moscow to Nizhny 1813]. Moscow, Society of Russian History and Antiquities of the Moscow University. 122 p.

Frolov, P.A. (2010). Sozdanie i krushenie sem'i Lermontovykh [Creation and collapse of the Lermontov's family]. In Sura: Zhurnal sovremennoy literatury, kul'tury i obshhestvennoy mysli. Penza. No. 3, pp. 151-184; No. 4, pp. 124-160.

Kanischev, V.V., Kondakov, R.B., Strekalova, N.V. (2006). Tehnologiya vosstanovleniya struktury gorodskoy sem'i $1917 \mathrm{~g}$. [Technology of restoration of the urban family structure in 1917]. In Informatsionniy byulleten' assotsiatsii "Istoriya i komp'yuter". No. 34, pp. 120-122.

Kanischev, V.V., Shuvaev, D.A. (2010). Baza dannyh "Dvoryanskaya sem'ya": problemy sozdaniya i interpretatsii [Database "Noble family": problems of creation and interpretation]. In Informatsionniy byulleten' assotsiatsii “Istoriya i komp'yuter”. No. 36, pp. 69-70.

Kol'chugina, S.V. (2011). Evolyutsiya predprinimatel'skoy pravosposobnosti russkoy zhenshhiny s drevnosti do nachala XX veka [Evolution of entrepreneurial legal capacity of Russian 
women from antiquity to the early $20^{\text {th }}$ century]. In XXI vek: itogi proshlogo $i$ problemy nastoyashchego plyus. No. 2 (02), pp. 155-161.

Komleva, E.V. (2016). Iz naslediya krasnoyarskih kuptsov Larionovykh [From the heritage of Krasnoyarsk merchants Larionov]. Vol. 1: Letters of the late $18^{\text {th }}-$ mid-19 ${ }^{\text {th }}$ century. Novosibirsk, Akademizdat. 324 p.

Komleva, E.V. (2018). "Gospodstvuyushhiy klass": sibirskie kuptsy v ehgo-tekstah chinovnikov (konets XVIII-XIX v.) [“The ruling class": Siberian merchants in the ego-texts of officials (late $18^{\text {th }}-$ $19^{\text {th }}$ century)]. In Lichnost', obshchestvo i vlast'v istorii Rossii: Sb. nauch. statey, posv. 70-letiyu d-ra istor. nauk, prof. V.I. Shishkina. Novosibirsk, pp. 53-73.

Korol'kov, M.Ya. (1908). Matereubiytsy. (Protsess Zhukovyh. Epizod iz sudebnoy hroniki XVIII stoletiya) [Materialize. (Process Zhukov. Episode from the judicial chronicle of the $18^{\text {th }}$ century)]. In Russkaya starina. St. Petersburg. Vol. CXXXIII. No. 1-3, pp. 225-231.

Marrese, M.L. (2019). Bab'e tsarstvo: Dvoryanki $i$ vladenie imushhestvom v Rossii (1700-1861) [A woman's Kingdom: Noblewomen and property ownership in Russia (1700-1861)]. Moscow, New literary review. 368 p.

Maslova, I.V. (2009). Struktura rodstvennyh svyazey i traditsii semeynogo byta uezdnogo kupechestva $\mathrm{v}$ Vyatskoy gubernii $\mathrm{v}$ XIX - nachale XX v. [The structure of family ties and traditions of family life of district merchants in Vyatka province in the $19^{\text {th }}-$ early $20^{\text {th }}$ century]. In Izvestiya Volgogradskogo gosudarstvennogo pedagogicheskogo universiteta. No. 8 (42), pp. 148-151.

Maslova, I.V. (2011). Kul'tura semeynyh traditsiy uezdnogo kupechestva Vyatskoy gubernii v XIX - nachale XX veka [Culture of family traditions of the County merchants of Vyatka province in the $19^{\text {th }}$ - early $20^{\text {th }}$ century]. In Vestnik Voronezhskogo gosudarstvennogo universiteta. Seriya: Istoriya. Politologiya. Sociologiya. No. 1, pp. 121-126.

Men'shikova, E.N. (2012). Analiz "vydayushhikhsya chert" istoricheskogo oblika zhenshhinykupchihi provintsial'noy Rossii v 60-90-e gg. XIX v. (Na primere kupecheskogo semeystva Gladkovyh iz Kurskoy gubernii) [The analysis of the "outstanding characteristics" of the historical image of women-widow of provincial Russia in the 60-90-ies of $19^{\text {th }}$ century (On the example of a merchant family Gladkov from the province of Kursk)]. In Zhenshchina v rossiyskom obshchestve. No. 2, pp. 24-33.

Men'shikova, E.N., Semenov, M.Yu. (2014). Konstruirovanie reprezentativnogo obraza zhenshhiny "novogo tipa" kontsa XIX - nachala XX veka [Construction of a representative image of a woman "of a new type" of the late $19^{\text {th }}$ - early $20^{\text {th }}$ century]. In Istoricheskaya psihologiya $i$ sociologiya istorii. Vol. 7. No. 2, pp. 117-131.

Mironov, B.N. (2000). Sotsial'naya istoriya Rossii perioda imperii (XVIII - nachalo XX v.): genezis lichnosti, demokraticheskoy sem'i, grazhdanskogo obshhestva i pravovogo gosudarstva [Social history of Russia during the Empire $\left(18^{\text {th }}-\right.$ early $20^{\text {th }}$ centuries): the Genesis of personality, democratic family, civil society and the rule of law] (in 2 vol.). Vol. 1. St. Petersburg, Dmitry Bulanin. 548 p.

Newerly (Abramov), I.N. (2014). Poslednie dni Pompei [The last days of Pompeii]. In Penzenskiy kray v memuarah, hudozhestvennoy literature $i$ issledovaniyah: Antologiya. Moscow. Vol. 1, pp. 243-256.

Obnorskaya, N.V. (2008). "Vse schastlivye sem'i pohozhi drug na druga, kazhdaya neschastlivaya sem'ya neschastliva po-svoemu": semeynye dramy v povsednevnoy zhizni kupechestva Yaroslavskoy gubernii vtoroy poloviny XIX - nachala XX veka ["All happy families are similar to each other, each unhappy family is unhappy in its own way": family drama in the daily life of the merchants of the Yaroslavl province of the second half of the $19^{\text {th }}-$ early $20^{\text {th }}$ century]. In Semeynaya zhizn'. Schastlivye $i$ dramaticheskie istorii na fone gorodskoy povsednevnosti: Materialy nauch. seminara, posv. issledovaniyam problem istorii povsednevnosti. Orenburg, pp. 87-94.

Pushkin, A.S. (1960). Evgeniy Onegin [Eugeny Onegin], Collected works (in 10 vol.). Vol. 4. Moscow, State publishing house of fiction, pp. 5-200. 
Semibratova, T.V. (1995). Zapiski o penzenskoy rodne [Notes on the Penza relatives]. In Zemstvo: Arhiv provincial'noy istorii Rossii. Penza. No. 1, pp. 67-99.

Strekalova, N.V. (2017). K probleme ispol'zovaniya informatsionnyh metodov i tehnologiy v issledovaniyah provintsial'noy gorodskoy sem'i kontsa XVIII - nachala XX v. [On the problem of the use of information methods and technologies in the studies of the provincial urban family of the late $18^{\text {th }}$ - early $20^{\text {th }}$ centuries]. In Cifrovaya gumanitaristika: resursy, metody, issledovaniya: Materialy Mezhdunar. nauch. konf. Part 2. Perm, pp. 114-117.

Veremenko, V.A. (2009). Dvoryanskaya sem'ya i gosudarstvennaya politika Rossii (vtoraya polovina $X I X-$ nachalo $X X v$ v.) [The family and state policy of Russia (the second half of $19^{\text {th }}-$ the beginning of $20^{\text {th }}$ century)]. St. Petersburg, "European House". $684 \mathrm{p}$.

Veremenko, V.A. (2017). Hozyayka na kuhne: adaptatsionnye praktiki v zhizni rossiyskoy dvoryanskoy sem'i vo vtoroy polovine XIX - nachale XX v. [Hostess in the kitchen: adaptation practices in the life of the Russian noble family in the second half of $19^{\text {th }}-$ early $20^{\text {th }}$ century]. In Ekstremal'noe v povsednevnoy zhizni naseleniya Rossii: istoriya i sovremennost' (k 100-letiyu russkoy revolyutsii 1917 g.): Materialy Mezhdunar. nauch. konf. St. Petersburg, pp. 295-315-323.

Vigel', F.F. (2003). Zapiski [Notes]. Book 2. Moscow, Zakharov, 752 p.

Zaytseva, O.M., Strekalova, N.V. (2018). Zyenshhina kupecheskogo sosloviya g. Tambova v kontse XIX - nachale XX veka: shtrikhi k sotsial'nomu portretu [A woman of the merchant class in the city of Tambov in the end of $19^{\text {th }}$ - early $20^{\text {th }}$ century: touches to the portrait of social]. In Vestnik Tambovskogo universiteta. Seriya Gumanitarnye nauki. Tambov. Vol. 23. No. 1 (171), pp. 145-155.

Статья поступила в редакиию 07.02.2019 г. 